\title{
A szemaglutid szerkezete és farmakológiája
}

\author{
Winkler Gábor dr.
}

\begin{abstract}
Összefoglalás
A szemaglutid a GLP-1-receptoragonisták legújabban forgalomba került változata. Jelenleg parenteralisan adagolható változata törzskönyvezett, de már elörehaladott vizsgálatok folynak szájon át alkalmazható formájával is. A jelen közlemény az injekciós készitmény szerkezeti sajátosságait, heti egyszer adagolható voltának strukturális hátterét, valamint farmakokinetikai és farmakodinámiai jellemzöit foglalja össze. Kitér hatékonyságára és biztonságosságára is.

Kulcsszavak: szemaglutid parenteralis változata, szerkezet, farmakokinetika, farmakodinámia, metabolizmus, elimináció
\end{abstract}

\section{Semaglutide: structure, pharmacokinetics and pharmacodynamics}

Summary: The semaglutide is the newest GLP-1-receptoragonist introduced into the clinical practice. Though at present only its parenteral formulation is approved, encouraging studies are already in progress also with the oral analogue. Molecular structure, pharmacokinetic and pharmacodynamic specialties of the injectable product are summarized in the present article. Efficacy, dosage and safety are also discussed.

Keywords: semaglutide parenteral form, structure, pharmacokinetics, pharmacodynamics, metabolism, elimination

\section{Rövidítések}

Cl: megbízhatósági tartomány (confidence interval); eGFR: becsült glomerularis filtrációs ráta; GLP-1: glukagonszerü peptid (glucagon-like peptide)-1; T2DM: 2-es típusú diabetes

$\mathrm{J}$ ól ismert, hogy a peptidek terápiás hasznosítását kis molekulaméretükből eredő felgyorsult clearence-ük és ennek következményeként rövid plazma féléletidejük sok esetben nehezíti. Ez utóbbi megnyújtása ezért hosszú ideje a gyógyszer-technológiai kutatások egyik kiemelt területe. Számos ezt segítő megoldás született: pegiláció (polietilén-glikol polimerhez történő kapcsolás), fúzió nagy molekulatömegủ peptidekkel, konjugáció albuminhoz kötődő ligandokkal.

Az utóbb említettek közé tartozik az ún. ,piggyback" stratégia (szó szerinti fordításban: a malacka hátához, értelem szerinti fordításban: hordozóhoz kapcsolás), amelynek lényege olyan dokkoló molekula keresése, amely lényegesen nem növeli a keringésben tartandó peptid molekulatömegét, ugyanakkor stabil fehérje (albumin)-kapcsolódást biztosít. Ilyen megoldás a zsírsavval történő aciláció, ${ }^{1}$ amely a glukagonszerű peptid (GLP)-1 tekintetében először a liraglutid esetében került alkalmazásra, s további módosításai vezettek a szemaglutid kifejlesztéséhez.

A jelen dolgozat a szemaglutid szerkezetét és főbb farmakokinetikai-farmakodinámiás tulajdonságait tekinti át. Összefoglalásunkban csak a parenteralis változat jellemzőit érintjük, a még fejlesztés alatt álló orális formulációval nem foglalkozunk.

\section{Molekulaszerkezet}

A szemaglutid a natív humán GLP-1 analógja. Szerkezete az eredeti molekulához képest három helyen módosult: 
1. az aminosavlánc 8-as pozíciójú alaninja helyén alfa-amino-izovajsav szerepel;

2. a 26-os pozíciójú lizinhez $\gamma$ Glu-2×OEG (gamma-glutamil $2 \times$ oligo[etilén-glikol]) spaceren (toldalékon) keresztül 18 szénatomos sztearinsav kapcsolódik;

3. a 34-es pozíciójú lizin argininre cserélt.

Az elsőként említett változás a dipeptidilpeptidáz (DPP)-4 hasításával szembeni rezisztenciát, a második módosulás pedig a stabil, de reverzibilis albuminhoz kötődést biztosítja. A harmadik aminosavcsere azt szolgálja, hogy az előállítás során az oktadekánsav-oldallánc csak a 26-os pozícióban kapcsolódjon és ne lépjen kapcsolatba az aminosavlánc másik lizinjével. Az említett szerkezetmódosulásokkal együtt a molekula jelentős, 94\%-os homológiát mutat a natív humán GLP-1-gyel., 2,3 (Az albumin „hordozómolekulakénti” hasznosítása azon a felismerésen alapul, hogy féléletideje 2,5-3,0 hét, így a stabilan hozzákapcsolódó molekulák plazmakeringésben való tartózkodása is megnyúlik, lehetővé téve az alapmolekulához képest ritkább adagolási gyakoriságot. ${ }^{4}$ )

Az előzőekben összefoglalt szerkezetmódosulás elemeit már a liraglutidnál is alkalmazták, a két származék féléletideje mégis jelentősen eltér egymástól (13 vs. kb. 168 óra). Ennek az az oka, hogy a liraglutidnál még nem szerepel a 8-as pozíciójú alanin felcserélése, továbbá a szemaglutidban a 16 szénatomos palmitinsav helyett 18 szénatomos zsírsav-oldallánc szerepel, ami az elózőtől eltérően diacilált, azaz stabilabb albuminkötődést biztosít. A szemaglutidban hosszabb a spacer is, ami az oldalláncnak nagyobb flexibilitást kölcsönöz, és ezáltal erősíti az albuminhoz való kapcsolódást ${ }^{5}$ (1. ábra).

A szemaglutid kis molekula, tömege 4,1 kilodalton $(\mathrm{kDa})$. Kis méretéből eredően átjut a vér-agy gáton és közvetlenül serkenti az agy GLP-1-receptorait az area postremában, a nucleus arcuatusban és a nucleus tractus solitariiben. Ezzel áll összefüggésben erőteljes étvágycsökkentő és súlyleadást elősegítő természete. ${ }^{2}$

A subcutan változat biohasznosulása $94 \%$, a legmagasabb a jelenleg forgalomban lévő GLP-1receptoragonisták között. ${ }^{2}$ (A subcutan változat kihangsúlyozása azért fontos, mert már III. fázisú vizsgálati szakaszba lépett az azonos molekulaszerkezetű orális szemaglutid is, amelynek biohasznosulása természetesen elmarad a parenteralisan adagolandó készítményétől.)

\section{Farmakokinetika és farmakodinámia}

Egyszeri subcutan beadást követően a maximális plazmakoncentráció 24-56 óra elteltével alakul ki. Egyenletes (steady state) plazmaszint hetenkénti beadással a 3. héttől kezdve mérhető, de már két egymást követő dózis beadása után megfigyelhető a steady state plazmaszint $75 \%-\mathrm{a}$. Az egyenletes vérszint heti $0,5 \mathrm{mg}$ adagolásakor 15,8 (95\%-os CI: $15,6-16,1) \mathrm{nmol} / \mathrm{l}$, heti egyszer $1,0 \mathrm{mg}$-os dózis választásakor 29,8 (95\%-os CI: 29,4-30,2) nmol/1. ${ }^{6}$ Populációs vizsgálatok szerint a farmakokinetikát

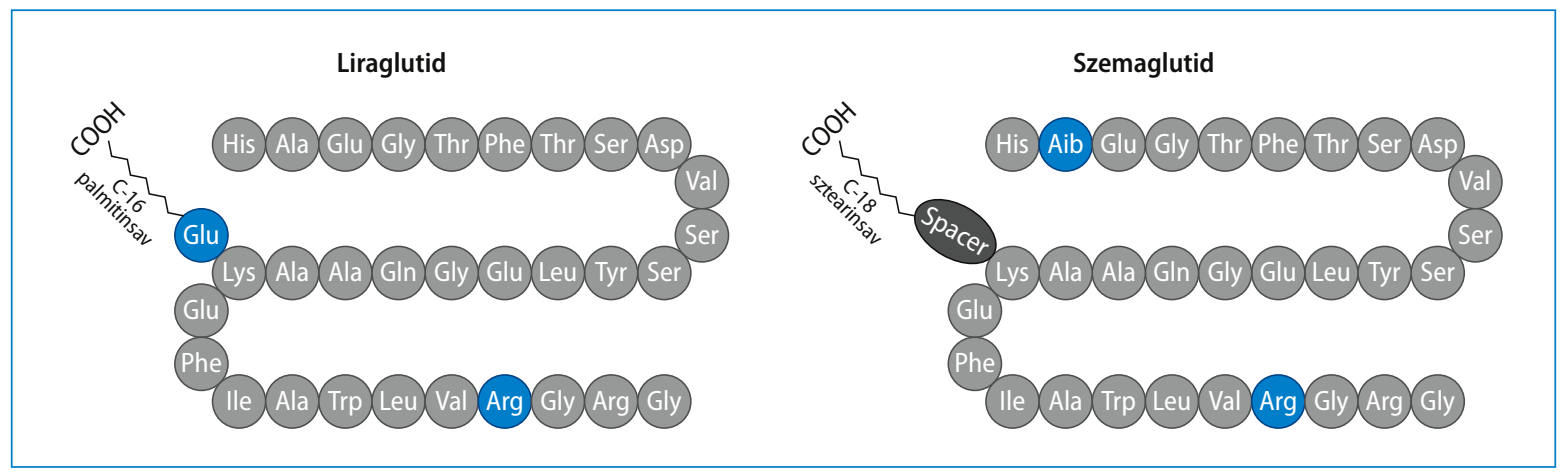

1. ábra. A liraglutid és a szemaglutid sémás szerkezete Feltüntettük azokat a különbségeket, amelyekben a molekulák a natív humán GLP-1-töl eltérnek. Megfigyelhető a két, egyezően zsírsav-oldalláncot tartalmazó GLP-1-analóg szerkezeti különbözése is 
a nem, az életkor, a rassz, az etnikum és az injekció beadásának helye nem befolyásolja. Inverz kapcsolat figyelhető meg viszont a tápláltsági állapot és a plazmaszint között: a testtömeg emelkedésével az egyszeri dózis beadását követően mért görbe alatti terület nagysága csökken. ${ }^{6} \mathrm{~A}$ farmakokinetikai jellemzők tartós adagolás során is változatlanok maradtak. ${ }^{6}$

A szemaglutid lebomlása részben a peptidlánc proteolitikus hasításával, részben a zsírsav-oldallánc béta-oxidációjával történik. Triciált molekulával végtett vizsgálatok szerint metabolizálódása során hat degradációs termék keletkezik (P1-P3, illetve P5-P7), a plazmában mért koncentráció túlnyomó részét, $82,6 \%$-át azonban a rövidült lánchosszúságú alapvegyület képezi. ${ }^{78}$ Metabolikusan aktív bomlásterméke nincs. A degradációs termékek plazmaszintje folyamatosan csökken, 28 nap elteltével már csak az alapmolekula jelenléte detektálható. ${ }^{7}$ Clearence-e $0,008 \mathrm{ml} / \mathrm{min}$, a dulaglutidé után a második legalacsonyabb a GLP1-receptoragonisták között. ${ }^{7}$

Döntő hányada (53\%) a vizelettel ürül, a vizeletben az alapmolekula mellett 21 bomlástermék izolálható. A széklettel 18,6\%, a kilélegzett levegővel 3,2\% távozik. Izotópvizsgálatok tanúsága szerint az alapmolekula a székletben nem jelenik meg. ${ }^{7}$

A szemaglutid farmakokinetikáját vizsgálták enyhe $\left(\right.$ eGFR $>60 \mathrm{ml} / \mathrm{min} / 1,73 \mathrm{~m}^{2}$ ), közepes (eGFR 59-30) és súlyos (eGFR <30) vesekárosodásban szenvedőkön, sőt dialízisre szoruló (eGFR <15) személyeken is. Azt találták, hogy a vesekárosodás mértéke érdemben nem befolyásolja a kinetikai viszonyokat. ${ }^{7,9}$ A SUSTAIN vizsgálatokban ugyan súlyos vesekárosodás fennállásakor a plazmaszintet 22\%-kal magasabbnak találták, azonban az érték az előre meghatározott „érdemi hatás nincs” kategórián belül maradt. ${ }^{10}$

Metabolizmusa fent összefoglalt mechanizmusa alapján nyilvánvaló, hogy a szemaglutid szervezetből történő ürülése részben hepatikus, részben renalis úton történik. Tanulmányozták ezért farmakokinetikáját különböző mértékű májkárosodásban szenvedőkön is, s plazmaszintjét, négy héten keresztül heti egyszer $0,5 \mathrm{mg}$ subcutan injiciálását követően számított kinetikai adatait egészséges májműködésű személyekével vetették össze. A krónikus májműködési zavart a Child-Pugh-beosztás szerint értékelték. Enyhe (score érték: 1, encephalopathia nem áll fenn, ascites nem észlelhető, szérumbilirubin $<34,2 \mu \mathrm{mol} / \mathrm{l}$, albumin $>35 \mathrm{~g} / \mathrm{l}$, protrombinidő $<4 \mathrm{sec}$ ), közepes (score: 2 , enyhe fokú encephalopathia, ascites észlelhető, de kevés, szérumbilirubin 34,2-51,3 $\mu \mathrm{mol} / 1$, albumin $28-35$ g/l, protrombinidő 4-6 sec-mal megnyúlt) és súlyos fokú károsodásban (score 3) szenvedőkön is vizsgálták a plazmaszint alakulását. (A besorolás szerinti enyhe májmüködési zavar Child-Pugh 1-3., a közepes 4-6., a súlyos $>6$. stádiumnak felelt meg.) Azt találták, hogy a májműködés károsodása érdemben nem befolyásolta a szemaglutid kinetikáját. Bár az albumintermelés jól ismert módon a máj károsodásának mértékével párhuzamosan csökken, a plazmában a fehérjéhez kötött szemaglutid aránya érdemben súlyos májkárosodásban szenvedőkön sem csökkent. ${ }^{8}$ (A teljesség kedvéért jegyezzük meg, hogy korábbi vizsgálatok ugyanezt találták a rokon szerkezetủ liraglutid és a döntő mértékben nem hepatikus mechanizmussal eliminálódó exenatid vonatkozásában is.) Az előzőekben áttekintett főbb farmakokinetikai és farmakodinamikai jellemzőket az 1. táblázatban is összefoglaljuk.

A 2-es típusú diabetes (T2DM) fokozott keringési kockázattal társuló megbetegedés, amelyben kiemelt jelentőségű a társult keringési kockázati tényezők egyidejű vizsgálata, és ha értékük a normálistól eltérő, kezelése. Fontos tehát annak tanulmányozása, hogy egy bevezetendő új készítmény befolyásolja-e a gyakran egyidejüleg szedett más készítmények szervezetbeli sorsát, vagy sem. A szemaglutid esetében azt találták, hogy egészségeseken ${ }^{11}$ és cukorbetegeken ${ }^{9}$ sincs kimutatható interakciója sem a T2DM vércukorcsökkentő

\section{1. táblázat. A parenteralisan adagolandó szemaglu- tid föbb farmakokinetikai adatai}

\begin{tabular}{|c|c|}
\hline Molekulatömeg & $4,1 \mathrm{kDa}$ \\
\hline Biohasznosulás & $94 \%$ \\
\hline Plazma féléletidő & kb. 168 óra \\
\hline $\begin{array}{c}\text { Steady state plazmaszint } \\
\text { kialakulásáig eltelt idő }\end{array}$ & 21 nap \\
\hline Metabolizmus & hepatikus és renalis \\
\hline Ürülés & vizelet (kb. 58\%), széklet (kb. 19\%) \\
\hline Adagolás & heti egyszer 0,25 - egyszer 1,0 mg \\
\hline
\end{tabular}


kezelésének - ellenjavallat, intolerancia hiányában - bázisát képező metformin, sem az atorvastatin, a warfarin vagy a digoxin metabolizmusával.

A szemaglutid hosszú hatású GLP-1-receptoragonista. A csoport más képviselőivel egyezően glukózfüggő módon serkenti az inzulinelválasztást és gátolja a glukagon release-t. A szemaglutid enyhén lassítja a korai postprandialis gyomorürülést, ezáltal lassítva azt a sebességet, amellyel a glukóz postprandialisan megjelenik a keringésben. ${ }^{12}$ Erőteljesen mérsékli az éhomi vércukorszintet és a napszakos glykaemiát is. Mind anyagcserejavító, mind súlyleadást elősegítő hatása a legerőteljesebb a jelenleg forgalomban lévő származékok között. Adagolásakor kismértékben csökken a systolés vérnyomás és - klinikailag nem releváns mértékben - emelkedik a pulzusszám. ${ }^{5,8,9}$

\section{Adagolás, biztonság}

Preklinikai vizsgálatokban, valamint prospektív randomizált-kontrollált tanulmányokban a szemaglutid heti egyszer 0,25 , illetve egyszer 0,5 és 1,0 mg-os dózisban, subcutan adagolással hatékonyan javította a glykaemiás kontrollt, mérsékelte az étvágyat és csökkentette a testsúlyt. A heti egyszer 1,0 mg-os adag anyagcsere-javító hatása felülmúlta az egyszer 0,25 , illetve az egyszer 0,5 mg-os dózisét. Hatékonyságát metaanalízisek is alátámasztják. ${ }^{13,14}$

Alkalmazását érdemi antitestképződés nem kíséri, ami a humán GLP-1-gyel való nagyfokú szerkezeti homológiája ismeretében nem meglepő. ${ }^{6,10}$ Más GLP-1-receptoragonistákkal egyezően, a részletes toxikológiai vizsgálatok keretében, rágcsálók mellett nem-humán emlősökön is tanulmányozták a pancreas hisztomorfológiáját érintő hatását. Cynomolgus majomtörzsön igazolták, hogy 4, 13 vagy 87 heti adagolása sem befolyásolta a pancreas tömegét, s nem okozott a kezeléssel összefüggésbe hozható szövettani változást. (Ugyanez volt megállapítható a rokon szerkezetű liraglutid vonatkozásában is. ${ }^{15}$ )

Mellékhatásként leggyakrabban nausea és gastrointestinalis diszkomfort panaszok fellépését észlelték. Az esetek túlnyomó részében enyhének és átmeneti jellegűnek bizonyultak. A SUSTAIN-6 vizsgálatban a retinopathia előfordulása az aktív (vs. placebo) ágon statisztikailag értékelhetően gyakoribb volt. Ez olyan személyeken fordult elő, akiknél retinopathia már a bevonáskor fennállt, a szemaglutid mellett bázisinzulint is kaptak és az elért $\mathrm{HbA}_{1 \mathrm{c}}$-csökkenés $\geq 2 \%$-os volt. ${ }^{16}$ A látás romlása a legtöbb esetben átmeneti volt. Hátterében a túl gyors vércukorcsökkenést valószínűsítik (amely jelenség az intenzív inzulinkezelés hajnalán több tanulmányban, pl. az Oslo, a Steno-1 stb. vizsgálatban szintén megfigyelhető volt). Mindenesetre, retinopathiás, inzulint is kapó személyeken a szemaglutid adása fokozott körültekintést igényel és a túl gyors $\mathrm{HbA}_{1 \mathrm{c}}$-csökkentés kerülendő!

A szemaglutid bármely napszakban adagolható, farmakokinetikáját a beadás helye nem befolyásolja, így akár hetente váltogatva, más-más testtájékon is adható. Hosszú hatástartamából eredően, ha egy adag bármely okból kimarad, 5 napon belül bármikor pótolható. Ha a szokásos beadástól számítva már több mint öt nap telt el, az adagot kihagyva, az esedékesség napján a következő adagot kell alkalmazni. Nem történik baj akkor sem, ha tévedésből egymást követő napon is beadásra kerül egy-egy dózis. A preklinikai vizsgálatok során volt erre példa, enyhe nauseától eltekintve más mellékhatást ilyenkor sem észleltek.

A kezelést heti egyszer 0,25 mg-mal kell kezdeni, s szükség szerint négy hét elteltével lehet a dózist heti egyszer $0,5 \mathrm{mg}$-ra emelni. Újabb négy hét szükséges az esetleges további dózisemeléshez (1,0 mg), de ennél nagyobb adag alkalmazására nem kerülhet sor. Bár törzskönyve szerint adható monoterápiában is, hazai gyakorlatunkban - a hatályos finanszírozási szabályozásból eredően - metformin mellett, második antidiabeticumként, vagy hármas kombinációban történő alkalmazása jön csak szóba. Hypoglykaemisáló hatású vércukorcsökkentővel, pl. szulfanilurea-vegyülettel együtt adva a nem kívánt vércukoresés kockázata fokozódik, ezért a hypoglykaemisáló szer korábbi adagjának csökkentése javasolt. (A kezelés egészét mérlegelve, megfontolandó a hypoglykaemisáló vegyület elhagyása és másik kombináció bevezetése.) 


\section{rrodalom}

1. Zorzi A: Development of an albumin-binding ligand for prolonging the plasma half-life of peptide therapeutics. École Polytechnique Fedérale de Lausanne, Thése № 7728 (2017). Lausanne, 2017. https://infoscience.epfl.ch/record/228335/files/EPFL_TH7728.pdf

2. Lau J, Bloch P, Schäffer L, Pettersson I, Spetzler J, Kofoed J, et al.: Discovery of the once-weekly glucagon-like peptide-1 (GLP-1) analogue semaglutide. J Med Chem 2015; 58 (18): 7370-7380. doi:10.1021/acs.jmedchem.5b00726

3. Guja C, Miulescu RD: Semaglutide - the "new kid on the block" in the field of glucagon-like peptide-1 receptor agonists? Ann TransI Med 2017; 5(23): 475. doi:10.21037/atm.2017.10.09

4. Sleep D, Cameron J, Evans LR: Albumin as a versatile platform for drug half-life extension. Biochym Biophys Acta 2015; 1830(12): 5526-5534. doi:10.1016/j.bbagen.2013.04.023

5. Holst JJ, Madspad S: Semaglutide seems to be more effective than other GLP-1 RAs. Ann TransI Med 2017; 5(24): 505. doi:10.21037/atm.2017.11.10

6. Carlsson Petri KC, Ingwersen SH, Flint A, Zacho J, Overgaard RV: Semaglutide s.c. once-weekly in type 2 diabetes: a population pharmacokinetic analysis. Diabetes Ther 2018; 9(4): 1533-1547. doi:10.1007/s13300-018-0458-5

7. Hall S, Isaacs D, Clements JN: Pharmacokinetics and clinical implications of semaglutide: a new glucagon-like peptide (GLP)-1 receptor agonist. Clin Pharmacokinet 2018; 57: 1529-1538. doi:10.1007/s40262-018-0668-z

8. Jensen L, Kupcova V, Arold G, Pettersson J, Hjerpsted JB: Pharmacokinetics and tolerability of semalglutide in people with hepatic impairment. Diabetes Obes Metab 2018; 20(4): 998-1005. doi:10.1111/dom.13186

9. Marbury TC, Flint A, Jacobsen JB, Karsbøl JD: Pharmacokinetics and tolerability of a single dose of semaglutide, a human glucagon-like peptide-1 analog, in subjects with and without renal impairment. Clin Pharmacokinet 2017; 5 (11): 1381-1390. doi:10.1007/s40262-017-0528-2

10. Shirakawa J, Terauchi Y: SUSTAINable management of type 2 diabetes: feasibility of use and safety of semaglutide. Editorial. Ann TransI Med 2018; 6(7): 129. doi:10.21037/atm.2018.01.35

11. Hausner H, Karsbøl JD, Holst AG, Jaconbsen JB, Wagner FD, Golor G, Anderson TW: Effect of semaglutide on the pharmacokinetics of metformin, warfarin, atorvastatin and digoxin in healthy subjects. Clin Pharmacokinet 2017; 56 (11): 1391-1401. doi:10.1007/s40262-017-0532-6
12. Hjerpsted JB, Flint A, Brooks A, Axelsen MB, Kvist T, Blundell J: Semaglutide improves postprandial glucose and lipid metabolism, and delays first-hour gastric emptying in subjects with obesity. Diabetes Obes Metab 2018; 20(3): 610-619. do: $10.1111 /$ dom. 13120

13. Shi F-H, Li H, Cui M, Zhang Z-L, Gu Z-C, Liu X-Y: Efficacy and safety of onceweekly semaglutide for the treatment of type 2 diabetes: a systematic review and metaanalysis of randomized controlled trials. Front Pharmacol 2018; 9: 576. doi:10.3389/fphar.2018.00576

14. Li X, Qie S, Wang X, Zheng Y, Liu Y, Liu G: The safety and efficacy of onceweekly glucagon-like peptide-1 receptor agonist semaglutide in patients with type 2 diabetes mellitus: a systemic review and meta-analysis. Endocrine 2018; 62(3): 535-545. doi:10.1007/s12020-018-1708-z

15. Gotfredsen CFG, Mølck A-M, Thorup I, Nyborg NCB, Salanti Z, Knudsen LB, et al: The human GLP-1 analogs liraglutide and semaglutide: absence of histopathological effects on the pancreas in nonhuman primates. Diabetes 2014; 63(7): 2486-2497. doi:10.2337/db13-1087

16. Vilsbøll T, Bain SC, Leiter LA, Lingvay I, Matthews D, Simó R, et al.: Semaglutide, reduction in glycated haemoglobin and the risk of diabetic retinopathy. Diabetes Obes Metab 2018; 20(4): 889-897. doi:10.1111/dom. 13172

Közlésre érkezett: 2019. február 10.

Közlésre elfogadva: 2019. március 6.

\section{A szerzö levelezési címe:}

\section{Dr. Winkler Gábor}

Szent János Kórház Budapest

1125 Budapest, Diós árok 1-3.

E-mail: gabor.winkler@janoskorhaz.hu 